\title{
ISTRI SEBAGAI PENCARI NAFKAH UTAMA PERSPEKTIF URF DAN AKULTURASI BUDAYA REDFIELD
}

\author{
Ahmad Agung Kurniansyah \\ Universitas Maulana Malik Ibrahim Malang \\ lakonagung@gmail.com
}

\section{Abstract}

This phenomenon generally happened in Hindus people, particularly Sudra-caste. In Bali, in Tegalingah village, most of people's caste was Sudra. The arrival of Islam in Tegalingah village, Mundukkunci, Sani Sari, Bali was first started by the arrival of Immigrating Muslims Bugis who stayed in Bali. Moreover, due to the direct contact between Islamic and local culture through trade transaction, marriage, and other factors caused acculturation between those two different cultures. On the other hand, this phenomenon caused the wife to run the main living as Muslim couple. From the background of the study above, this research aimed to know the reason why the wife must be the main living couple in Mundukkunci, Sani Sari, Bali, and to know the wife's status as the main living couple in culture's acculturation perspective by Redfield. The research belonged to field research in the form of case study. The data used was primary data and done by interview and documentation. Then, it was analyzed using theory of Culture Acculturation by Redfield, and verified using triangulation data method. The results of the research showed that:1. There were three factors causing the wife became the main living couple in Mundukkunci, Sani Sari, Bali. Those were, first, inability of the husband to meet family needs, second, lack of husband's income to meet household needs, third, tradition. 2. In term of urf, the phenomenon of the wife as the main living couple was divided into two kinds, first, urf shohih, second, urf fasid. Besides, there were three forms of culture acculturation in this research. First: hereditary, it can be seen from the women's inheritance right obtained by Hindus' women when they became Muslims, as the implication from the collective right between husband and wife. Second: syncretism, it can be seen from the collaboration and responsibility between husband and wife to fulfill family's needs. Third: rejection, this case occurred when the wife's role as the main living couple replaced by the wife as husband's assistance or work together with the husband in fulfilling the household needs.

Keywords: Culture Acculturation, Wife, Main Living Couple

\section{Abstrak}

Fenomena ini umumnya terjadi pada umat Hindu Sudra-kasta. Kebanyakan orang di desa Tegalinggah adalah kasta Sudra. Kedatangan Islam di Desa Tegalinggah, Mundukkunci, RW Sani Sari dimulai dengan kedatangan Muslim Bugis yang bermigrasi dan tinggal di Bali. Dalam kehidupan sehari-hari mereka, orang Bugis dibimbing oleh ajaran Islam. Karena ada kontak langsung antara budaya Islam dan budaya lokal melalui transaksi perdagangan, pernikahan dan lainnya, sehingga ada akulturasi antara kedua budaya tersebut. Fenomena ini menyebabkan istri menjalankan nafkah utama sebagai pasangan Muslim. Penelitian ini bertujuan untuk mengetahui latar belakang munculnya istri sebagai pencari nafkah utama di Mundukkunci, RW Sani Sari, Singaraja Bali juga untuk mengetahui status istri sebagai pencari nafkah utama dalam perspektif akulturasi budaya oleh Redfield. Ini adalah penelitian lapangan dalam bentuk studi kasus. Data yang digunakan adalah data primer yang peneliti peroleh dari wawancara dan dokumentasi, kemudian data dianalisis menggunakan teori akulturasi budaya Redfield, untuk 
mengecek keabsahan data peneliti menggunakan metode triangulasi data. Hasil penelitian menunjukkan bahwa: 1. ada tiga faktor yang menjadi latar belakang munculnya fenomena istri sebagai pencari nafkah utama di RW Sani Sari, Desa Mundukkunci, Kabupaten Singaraja, dan Provinsi Bali. pertama, faktor ketidakmampuan suami untuk memenuhi kebutuhan keluarga. Kedua, karena kurangnya pendapatan suami dalam memenuhi kebutuhan rumah tangga. Ketiga, karena faktor tradisi. 2. Dalam hal Urf, fenomena istri sebagai pencari nafkah utama dibagi dua. Pertama, Urf Shohih. Kedua, Urf Fasid. Ada tiga bentuk akulturasi budaya dalam penelitian ini. Pertama: asal mula, asal mula dapat dilihat dalam hak-hak warisan yang diperoleh oleh wanita Hindu ketika mereka masuk Islam sebagai implikasi dari hak kolektif antara suami dan istri. Kedua, sinkretisme dapat dilihat dari kolaborasi dan tanggung jawab bersama antara suami dan istri untuk memenuhi kebutuhan keluarga. Ketiga, penolakan dalam kasus ini terjadi ketika istri sebagai pencari nafkah utama diganti dengan istri sebagai asisten suami atau bekerja sama dengan suaminya dalam memenuhi kebutuhan rumah tangga.

Kata Kunci: Akulturasi Budaya, Istri, Pencari Nafkah Utama

\section{PENDAHULUAN}

Fenomena perempuan sebagai pencari nafkah utama merupakan fenomena yang sudah dianggap biasa terjadi oleh masyarakat Bali.Umumnya fenomena tersebut terjadi pada pasangan suami istri yang beragama Hindu yang berkasta Sudra. Kasta Sudra merupakan kasta yang paling rendah di antara kasta - kasta yang berlaku pada agama Hindu Bali.Sebagian besar masyarakat Hindu di Desa Tegalinggah berkasta Sudra dan Waisya, sebagaimana tugas bagi masyarakat yang berkasta Sudra yang biasa menjadi pekerja kasar dan serabutan, maka tidak sedikit ditemukan perempuan - perempuan di Desa Tegalinggah melakukan pekerjaan kasar seperti mencangkul, mengaspal jalan bahkan memanjat pohon cengkeh demi menjalankan tugas sebagai kasta Sudra dan untuk memenuhi kebutuhan keluarga.

Umat Islam di Desa Tegalinggah khususnya di RW Sani Sari merupakan pendatang dari suku Bugis (Sulawesi) yang tinggal dan menetap di daerah tersebut, dalam kesehariannya mereka biasa hidup berdampingan dengan masyarakat Hindu. Dampak yang muncul akibat hidup berdampingan dengan masyarakat Hindu dari waktu ke waktu secara tidak langsung mempengaruhi masyarakat Islam yang ada di desa tersebut. Kontak langsung yang terjadi sehari-hari antara masyarakat Hindu Bali dengan masyarakat muslim menyebabkan terjadinya akulturasi budaya antara kedua masyarakat tersebut. Akulturasi tersebut berimplikasi pada pasangan suami istri yang beragama Islam sehingga tidak sedikit fenomena istri sebagai pencari nafkah utama juga ditemukan pada pasangan suami istri yang beragama Islam.

Berdasarkan hasil wawancara dengan Jamuri pad tanggal 26 Oktober 2018:

"Di desa ini peneliti mendapati tujuh pasangan suami istri yang istrinya sebagai pencari nafkah utama, pekerjaan mereka berbeda - beda, di antaranya ada yang menjadi buruh kapuk, pedagang kapuk,mencari emas, pedagang kelontong,buruh kambing dan mencari rongsokan".

Di RW Sani Sari, Dusun Mundukkunci, Desa Tegalinggah, Kabupaten Singaraja, Provinsi Bali, istilah perempuan sebagai pencari nafkah utama tidak digunakan 
oleh masyarakat setempat, mereka lebih suka menggunakan istilah perempuan sebagai pembantu suami dalam mencari nafkah.

Ada beberapa hal yang menyebabkan istri bekerja bahkan terpaksa mengambil alih peran sebagai pencari nafkah utama. Di antaranya yang paling dominan karena pengaruh budaya lokal, ketidakmampuan suami dalam mencari nafkah, dan karena kurangnya penghasilan suami dalam mencukupi kebutuhan rumah tangga.

Fenomena istri sebagai pencari nafkah utama tentu sangat bertentangan dengan nilai-nilai Islam, Undan-Undang dan Kompilasi Hukum Islam di Indonesia. Dalam Undang-Undang Perkawinan Pasal 34 ayat 1 Tahun 1974 disebutkan "suami wajib melindungi istrinya dan memberikan kebutuhan rumah tangga sesuai dengan kemampuannya".

Dalam Kompilasi Hukum Islam (KHI) Pasal 80 ayat (2) disebutkan bahwa "kewajiban suami memberikan perlindungan terhadap istri dan memenuhi kebutuhan rumah tangga sesuai dengan kemampuannya". Juga dijelaskan dalam Pasal 80 ayat (4) beberapa hal yang harus ditanggung suami sesuai dengan pendapatannya di antaranya:

1. Nafkah, kiswah dan tempat tinggal.

2. Biaya rumah tangga, biaya perawatan dan biaya pengobatan anak dan istri.

3. Biaya pendidikan anak.

Di dalam al - Qur'an juga dijelaskan bahwa suami wajib memberi nafkah kepada istrinya, hal ini sebagaimana dalam surat $\mathrm{Al}$ Baqarah ayat 233.

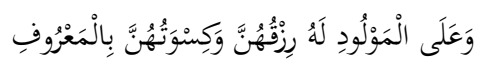

"Dan kewajiban ayah memberikan makanan dan pakaian kepada para ibu dengan cara yang ma'ruf.

Thalib (1999: 108-109), Memang Islam membolehkan perempuan bekerja tetapi bukan berarti ia sebagai pencari nafkah utama, berikut beberapa syarat yang harus dipenuhi perempuan ketika hendak bekerja, di antaranya:

1. Pekerjaan yang dilakukan memang memerlukan tenaga perempuan, seperti menjadi pengusaha, suster bagi pasien perempuan, guru TK, dan lain- lain yang berkenaan dengan tenaga perempuan.

2. Pekerjaan yang dilakukan tidak menggugurkan kewajiban perempuan sebagai ibu rumah tangga. Jika hal itu terjadi maka selayaknya perempuan tidak perlu melakukan pekerjaan tersebut.

3. Harus mendapat izin dari suami, jika perempuan tersebut belum menikah maka harus ada izin dari ayah atau saudara laki-laki.

Perlunya diterapkan syarat-syarat di atas bertujuan untuk menjaga keselamatan dan keamanan perempuan dari hal-hal yang merugikannya,tetapi pada dasarnya selama norma-norma agama dan susila tetap terpelihara maka tidak ada ketentuan apakah perempuan itu harus bekerja di satu tempat, baik di dalam atau di luar rumah, hal tersebut bebas dilakukannya karena perempuan juga memiliki hak untuk bekerja (Islamiah, 2010: 138). 
Dari uraian atas, peneliti ingin mengetahui lebih dalam terkait fenomena istri sebagai pencari nafkah utama yang terjadi di dusun tersebut. Oleh karena itu peneliti memfokuskan konteks penelitian pada penelitian ini dalam dua hal. Pertama,. Apa saja hal-hal yang melatarbelakangi terjadinya fenomena istri sebagai pencari nafkah utama di RW Sani Sari, Dusun Mundukkunci, Desa Tegalinggah, Kabupaten Singaraja, Provinsi Bali. Kedua,. Bagaimana fenomena istri sebagai pencari nafkah utama di RW Sani Sari, Dusun Mundukkunci, Desa Tegalinggah, Provinsi Bali bila ditinjau dari perspektif urf dan akulturasi budaya Redfield.

\section{KAJIAN PUSTAKA \\ Konsep Nafkah}

Islamiah (2010: 135) secara harfiah, nafkah merupakan sesuatu yang harus dikeluarkan terhadap orang yang menjadi tanggungannya. Kewajiban nafkah menurut Al-Qur'an dibebankan kepada laki-laki (suami).

"Dan kewajiban ayah memberikan makanan dan pakaian kepada para ibu dengan cara yang ma'ruf".

Tujuan diberikannya tanggung jawab nafkah atas suami karena Islam tidak ingin membebani perempuan secara berlebihan. Bagi Masdar karena istri sudah menanggung beban reproduksi yang menekan beban fisik dan mental maka sangat masuk akal jika tanggung jawab nafkah diletakkan di pundak suami.

Jumhur ulama berpendapat nafkah merupakan kewajiban yang bersifat tetap bagi suami.Menurut jumhur ulama kewajiban nafkah gugur jika istri tidak melaksanakan kewajibannya (nusyuz).

Sebaliknya menurut jumhur ulama jika suami tidak memberikan nafkah maka istri berhak tidak memberikan pelayanan kepada suami bahkan istri berhak membatalkan perkawinan. Di Indonesia jika terdapat perselisihan tentang nafkah antara suami istri maka diselesaikan di Pengadilan Agama.

\section{Hak dan Kewajiban Suami Istri}

a. Hak bersama suami istri

Dengan adanya akad nikah maka suami istri mempunyai hak dan kewajiban bersama di antaranya:

1) Suami istri dihalalkan mengadakan hubungan seksual.

2) Haram melakukan pernikahan, maksudnya antara suami istri haram melakukan pernikahan antara saudaranya masing-masing.

3) Dengan pernikahan maka kedua pihak berhak saling mewarisi jika salah satu di antara keduanya meninggal meskipun belum bersetubuh.

4) Kedua pihak wajib bertingkah laku baik sehingga tercipta kemesraan dan ketentraman hidup. 
5) Anak yang lahir mempunyai nasab yang jelas.

b. Kewajiban suami istri

Dalam Kompilasi Hukum Islam (KHI) disebutkan bahwa, kewajiban suami istri secara rinci di antaranya (Utsman, 2017: 157):

1) Suami istri wajib memelihara kehormatannya.

2) Masing-masing berhak mengajukan gugatan jika salah satu dari kedua pihak melalaikan kewajibannya.

3) Suami istri wajib mencintai, setia, menghormati, dan memberikan bantuan lahir batin.

4) Suami istri memikul kewajiban untuk menegakkan rumah tangga yang sakinah, mawadah, warahmah, yang merupakan sendi dasar dari susunan masyarakat.

5) Suami istri wajib memelihara dan mengasuh anaknya baik mengenai pertumbuhan jasmani, rohani maupun kecerdasan dan pendidikan agama anaknya.

\section{Konsep Urf}

Urf atau adat merupakan dua kata yang sering dibicarakan dalam kajian ushul fiqh. Dua kata tersebut berasal dari bahasa Arab. Kata adat sekarang diserap ke dalam bahasa Indonesia yang baku (Syarrifuddin, 2009: 386). Urf secara harfiah adalah suatu keadaan, ucapan, maupun perbuatan yang dikenal manusia dan telah menjadi tradisi untuk dilaksanakan atau ditinggalkan. Di kalangan masyarakat,urf sering disebut adat (Syafe'i, 1999: 128).

Macam-macam urf dapat dilihat dari beberapa segi, baik dari segi materi yang biasa dilakukan, ruang lingkup penggunaannya dan dari segi penilaian baik buruknya.

1. Dari segi materi yang biasa dilakukan,urf dibagi menjadi dua macam yaitu Urf qauli.dan Urffi'ly.

2. Dari segi ruang lingkupnya urf terbagi menjadi dua bagian yaitu. Urf umum dan urf khusus.

3. Dinilai dari segi baik buruknya suatu pekerjaan urf dibagi menjadi dua yaitu urf shohih dan urffasid.

Penyerapan adat dalam hukum Islam dibagi empat, proses seleksi ini bertujuan untuk membedakan mana adat yang boleh diberlakukan dan tidak boleh diberlakukan kemudian. Berdasarkan seleksi tersebut adat dibagi menjadi empat yaitu :

1. Adat lama secara substansial yang dalam pelaksanaannya mengandung unsur ke-maslahatan. Atau unsur maslahat-nya lebih besar daripada unsur mudharat-nya, adat dalam hal ini diterima sepenuhnya oleh hukum Islam.

2. Adat lama yang secara substansial dianggap baik oleh Islam sedangkan dalam pelaksanaannya tidak dianggap baik oleh Islam.

3. Adat lama yang secara substansial mengandung unsur mafsadat atau mafsadat-nya lebih besar daripada manfaatnya. Adat ini secara mutlak ditolak oleh ajaran Islam.

4. Adat atau urf yang yang sudah lama adanya yang tidak mengandung unsur mafsadah juga tidak bertentangan dengan dalil syara' yang datang kemudian 
namun secara tegas belum terserap oleh syara' baik secara langsung maupun tidak langsung. Adat semacam ini jumlahnya banyak sekali dan menjadi perbincangan di kalangan ulama. Bagi ulama yang mengakuinya berlaku kaidah العادة محكمة adat itu dapat menjadi dasar hukum.

\section{Teori Akulturasi Budaya}

Akulturasi terjadi apabila terdapat pertemuan antar individu dari dua kebudayaan yang berbeda yang saling berhubungan secara intensif sehingga menimbulkan perubahan besar pada pola kebudayaan salah satu dari kebudayaan tersebut atau kedua budaya tersebut (Pujileksono, 2015: 248). Menurut Haviland. Variabel yang mempengaruhi akulturasi didasarkan pada tingkat perbedaan kebudayaan, keadaan, intensitas, frekuensi dan semangat persaudaraan dalam arti yang dominan yang mempengaruhi, yang lemah yang tunduk dan apakah datangnya pengaruh itu ada hubungan timbal balik atau tidak. Menurut Garbarino "Akulturasi (adalah) proses perubahan budaya sebagai akibat jangka panjang, tatap muka, kontak langsung antara dua masyarakat. Menurut Redfield, Linton, Herskovits, Akulturasi meliputi fenomena yang timbul sebagai hasil, jika kelompok-kelompok manusia yang mempunyai kebudayaan yang berbeda-beda bertemu, dan mengadakan kontak secara terus menerus yang kemudian menimbulkan perubahan dalam pola kebudayaan yang original dari salah satu kelompok atau kedua-duanya. Dari berbagai pendapat para ahli mengenai definisi akulturasi di atas dapat disimpulkan bahwa akulturasi adalah suatu proses yang dilakukan sejak pertama kali terjadinya kontak dengan budaya lain agar beradaptasi dengan budaya baru (Adhiputra, 2013: 68).

Dalam mengamati akulturasi budaya terdapat beberapa hal yang perlu diperhatikan di antaranya (Koentjadiningrat, 2009: 205):

1. Keadaan masyarakat sebelum terjadi akulturasi.

2. Individu yang membawa unsur budaya asing.

3. Saluran yang dilalui budaya asing untuk masuk pada budaya lokal.

4. Bagian dari masyarakat yang terpengaruh budaya asing.

5. Reaksi individu yang terpengaruh unsur budaya asing.

Terkait suatu yang terjadi dalam akulturasi para ahli antropologi menggunakan istilah berikut di antaranya (Pujileksono, 2015: 248) :

1. Adisi (addition) ialah dimana unsur - unsur baru ditambahkan pada unsur unsur lama. Dalam hal ini bisa terjadi atau tidak terjadi perubahan struktural.

2. Sinkretisme ialah unsur - unsur lama bercampur dengan unsur - unsur baru dan membentuk sebuah sistem baru.

3. Substitusi (substitution) ialah kompleksnya unsur-unsur budaya yang ada sebelumnya diganti oleh unsur-unsur budaya baru terutama yang dapat memenuhi fungsinya yang melibatkan perubahan struktur yang sangat kecil.

4. Dekulturasi (deculturation) ialah bagian substansial kebudayaan yang mungkin hilang. 
5. Penolakan (rejection), ialah perubahan mungkin terjadi begitu cepat sehingga sejumlah besar orang tidak dapat menerimanya, hal ini dapat menimbulkan penolakan bahkan pemberontakan atau gerakan kebangkitan.

\section{METODE PENELITIAN}

\section{Pendekatan dan Jenis Penelitian}

Metode penelitian ini menggunakan pendekatan kualitatif. Pendekatan ini digunakan untuk menghasilkan data deskriptif berupa kata-kata tertulis atau lisan dari orang atau prilaku yang diamati dan selanjutnya dikuatkan dengan sumber data primer dan sumber data sekunder (Amiruddin dan Asikin, 2006: 133).

Bentuk penelitian yang digunakan dalam penelitian ini yaitu penelitian empiris dalam bentuk studi kasus. Studi kasus dipilih untuk meneliti suatu kasus yang mempunyai batasan - batasan yang jelas (Crewswell, 2013: 173).

\section{Kehadiran Peneliti}

Sebagai upaya untuk mendapatkan data-data yang valid dan obyektif terhadap apa yang diteliti, maka kehadiran peneliti di lapangan mutlak diperlukan. Dalam hal ini peneliti sebagai instrumen dan alat pengumpul data.

\section{Latar Penelitian}

Berdasarkan judul dan permasalahan yang diangkat dalam penelitian ini maka penelitian ini dilakukan di Dusun Mundukkunci, RW Sani Sari, Desa Tegalinggah, Kabupaten Singaraja, Provinsi Bali. Pertimbangan akademik yang dilakukan peneliti sehingga peneliti melakukan wawancara di desa tersebut karena di desa tersebut sudah biasa terjadi fenomena istri sebagai pencari nafkah utama.

\section{Data dan Sumber Data Penelitian}

Sumber data dalam penelitian ini dibagi menjadi dua Pertama,. sumber data primer. Kedua, Sumber data sekunder. Data primer dalam penelitian ini yaitu data hasil wawancara pada pasangan suami istri muslim yang istrinya menjadi pencari nafkah utama. Data sekunder dalam penelitian ini yaitu buku-buku, kamus, tesis, disertasi, jurnal, artikel yang berhubungan dengan pembahasan istri sebagai pencari nafkah utama, urf dan akulturasi budaya.

\section{Pengumpulan Data}

Dalam melakukan penelitian, untuk mendapatkan kesimpulan dan hasil yang terarah, peneliti melakukan beberapa metode pengumpulan data, di antaranya Pertama, metode wawancara (interview) dalam penelitian ini peneliti melakukan wawancara kepada beberapa pasangan suami istri yang istrinya sebagai pencari nafkah utama. Kedua, Dokumentasi.

\section{Analisis Data}

Setelah proses pengumpulan data, kemudian data diolah dan dianalisa untuk memecahkan permasalahan sesuai dengan tujuan peneliti, dalam proses analisis ini diperlukan beberapa tahap yaitu: Pertama, editing. Editing adalah merangkum dan memilih data pokok untuk disesuaikan dengan fokus penelitian. Kedua,. klasifikasi, klasifikasi adalah mengelompokan data sesuai dengan topik penelitian. Dalam hal ini 
peneliti mengelompokan data menjadi empat bagian. Pertama, data-data terkait konsep nafkah. Kedua, data-data terkait hak dan kewajiban suami istri. Ketiga, data-data terkait konsep urf. Keempat, data-data terkait teori urf dan akulturasi budaya Redfield. Ketiga,verifikasi. Verifikasi merupakan pemeriksasan kembali dengan cermat dari datadata yang sudah terkumpul dan terklasifikasi supaya tidak terjadi kerumitan dalam memahaminya. Keempat, analisa. Analisa yaitu menganalisis data guna memperoleh kesimpulan akhir, hal ini dilakukan dengan mengklasifikasi data-data terkait fenomena istri sebagai pencari nafkah utama kemudian data tersebut diverifikasi kemudian dianalisis menggunakan urf dan teori akulturasi budaya Redfield. Kelima, kesimpulan. Kesimpulan merupakan jawaban dari fokus penelitian yang dalam hal ini peneliti akan menjawab latar belakang terjadinya fenomena istri sebagai pencari nafkah utama dan fenomena istri sebagai pencari nafkah utama prespektif urf dan akulturasi budaya Redfield.

\section{Keabsahan Data}

Dalam menguji keabsahan data peneliti menggunakan metode trianggulasi di antaranya trianggulasi sumber. Sumber dalam penelitian ini berupa hasil wawancara di antara pasangan suami istri muslim yang istrinya sebagai pencari nafkah utama, tokoh masyarakat di Dusun Mundukkunci, RW Sani Sari, Desa Tegalinggah, Provinsi Bali, juga dari literatur-literatur yang berkaitan dengan fenomena istri sebagai pencari nafkah utama Trianggulasi Teknik. Kedua, trianggulasi teknik, disini peneliti menguji data terkait istri sebagai pencari nafkah utama perspektif akulturasi budaya Redfield melalui dokumen yang berkaitan dengan pembahasan tersebut. Ketiga, trianggulasi Waktu, waktu juga berpengaruh dalam menguji kredibilitas data. Seperti data yang dikumpulkan pada saat pagi hari ketika narasumber masih segar berpengaruh pada kevalidan data.

\section{HASIL PENELITIAN DAN PEMBAHASAN}

Beberapa hal yang mendorong istri mengambil peran sebagai pencari nafkah utama di antaranya:

1. Ketidakmampuan suami dalam mencari nafkah.

2. Kurangnya penghasilan suami.

3. Faktor adat atau budaya turun temurun.

Adapun uraian yang menjelaskan setiap poin tersebut adalah sebagai berikut:

1. Ketidakmampuan suami dalam mencari nafkah.

Jika istri sebagai pencari nafkah disebabkan karena ketidakmampuan suami dalam mencari nafkah maka istri diberi pilihan antara bersabar atau membatalkan perkawinan (fasakh). Jika istri sabar akan kondisi suami kemudian ia menafkahi dirinya atau berhutang untuk mencukupi kebutuhan hidupnya maka yang demikian merupakan hutang bagi suami yang harus dibayar kepada istri ketika suami memiliki kemampuan, dengan catatan sesuatu yang dikeluarkan istri untuk dirinya tidak melebihi batas yang wajib dikeluarkan suami. Hal ini karena hukum memberi nafkah pada istri adalah wajib (Syarifuddin, 2009: 166). 
Fenomena istri sebagai pencari nafkah utama karena ketidakmampuan suami dalam mencari nafkah tentunya bertentangan dengan Undang-Undang dan ajaran Islam. Dalam Pasal 107 ayat (2) KUHPer: suami berkewajiban melindungi istrinya dan memberikan istrinya sesuatu yang patut sesuai dengan pendapatannya. Dalam UndangUndang Perkawinan Pasal 34 ayat 1 Tahun 1974 juga disebutkan kewajiban nafkah bagi suami yang berbunyi suami wajib melindungi istrinya dan memberikan kebutuhan rumah tangga sesuai dengan kemampuannya. Kewajiban nafkah bagi suami juga disebutkan Dalam Kompilasi Hukum Islam (KHI) Pasal 80 ayat (2) yang berbunyi: suami wajib melindungi istrinya dan memberikan segala keperluan hidup rumah tangga sesuai dengan kemampuannya. Dan dalam Pasal 80 ayat (4) KHI berbunyi: sesuai penghasilannya, suami menanggung :

1. Nafkah, kiswah dan tempat kediaman istri.

2. Biaya rumah tangga, biaya perawatan dan biaya pengobatan istri dan anak.

3. Biaya pendidikan anak.

Fenomena istri sebagai pencari nafkah utama yang disebabkan karena ketidakmampuan suami dalam mencari nafkah, sekalipun bertentangan dengan ajaran Islam, namun bila ditinjau dari segi urf dalam hal keabsahannya dalam pandangan syara', bagi peneliti fenomena ini termasuk urf shohih karena adat tersebut sudah diterima oleh orang banyak, tidak melanggar agama, tidak bertentangan dengan sopan santun, juga jika dikaitkan dengan fenomena istri sebagai pencari nafkah utama yang terjadi di desa tersebut, mereka (pasangan suami istri yang istrinya sebagai pencari nafkah utama) sudah rela menjadi pencari nafkah utama, maka adat ini diperbolehkan. Bagi peneliti, jika adat istri sebagai pencari nafkah utama dilarang maka mafsadah yang timbul kemudian akan lebih besar daripada maslahat yang didapat seperti akan banyaknya kasus perceraian di antara pasangan suami istri dikhawatirkan berimplikasi negatif pada anak.

2. Kurangnya penghasilan suami.

Jika istri sebagai pencari nafkah utama disebabkan karena kurangnya penghasilan suami. Dalam hal ini bagi peneliti perlu dilihat dulu bagaimana suami dalam mencari nafkah, jika suami tidak mau berusaha lebih keras dalam mencari nafkah dan sehari-hari hanya hidup mengandalkan penghasilan istri, maka suami tersebut dikatakan suami yang melalaikan tanggung jawabnya, maka adat istri sebagai pencari nafkah utama dalam hal ini dikategorikan sebagai adat fasid. Dalam hal ini istri boleh membatalkan perkawinan atau bersabar melanjutkan perkawinan. Dan istri boleh menuntut suaminya di Pengadilan karena suami melalaikan kewajibannya. Perihal penuntutan ini dijelaskan dalam Pasal 34 ayat (3) UU Perkawinan : Bilamana antara suami istri melalaikan kewajibannya maka di antara keduanya berhak untuk menggugat di Pengadilan baik Pengadilan Negeri maupun Agama tergantung dengan agama antara suami istri tersebut.

3. Faktor adat atau budaya turun temurun

Fenomena istri sebagai pencari nafkah utama yang terjadi di RW Sani Sari, Dusun Mundukkunci, Desa Tegalinggah, Kabupaten Singaraja, Provinsi Bali merupakan dampak dari akulturasi budaya antara pasangan suami istri yang beragama Hindu yang 
berkasta Sudra dengan masyarakat Islam. Bagi peneliti, fenomena istri sebagai pencari nafkah utama yang membudaya selama berabad - abad di Bali masuk pada kaidah العادة yang dalam pelaksanaannya haruslah memenuhi beberapa persyaratan. Di antara syarat yang ditetapkan ulama dalam menerima urf yaitu:

1. Adat atau urf bernilai maslahat dan dapat diterima akal sehat.

2. Adat tersebut belaku umum di masyarakat tertentu atau sebagian besar dari suatu masyarakat.

3. Urf yang dijadikan sandaran hukum merupakan urf yang ada sejak dahulu bukan urf yang datang kemudian.

4. Adat tidak bertentangan dengan nilai syara' yang ada atau bertentangan dengan prinsip yang pasti.

Adapun uraian dari syarat - syarat di atas adalah sebagai berikut:

1. Adat atau urf bernilai maslahat dan dapat diterima akal sehat.

Jika peneliti hubungkan dengan fenomena istri sebagai pencari nafkah utama yang rela menjadi pencari nafkah utama dan memilih melanjutkan pernikahan daripada bercerai, bagi peneliti tindakan istri mengambil posisi sebagai pencari nafkah utama masuk akal karena dengan menjadi pencari nafkah utama maka kebutuhan ekonomi keluarga bisa tercukupi sehingga maslahat-nya dapat dirasakan sekeluarga, sebaliknya jika istri tersebut meninggalkan suami atau membatalkan perkawinan maka bagi peneliti, dihawatirkan akan timbul perceraian yang kemudian berdampak buruk pada kondisi anak dan keluarga antara suami istri.

2. Adat tersebut belaku umum di masyarakat tertentu atau sebagian besar dari suatu masyarakat.

Fenomena istri sebagai pencari nafkah utama yang terjadi di RW Sani Sari, Desa Tegalinggah merupakan fenomena yang sudah umum dan menyeluruh terjadi di masyarakat setempat.

3. Urf yang dijadikan sandaran hukum merupakan urf yang ada sejak dahulu bukan urf yang datang kemudian.

Fenomena istri sebagai pencari nafkah utama yang terjadi di RW Sani Sari merupakan fenomena yang terjadi sudah berabad-abad sehingga masyarakat desa setempat sudah terbiasa sejak dulu melihat fenomena istri sebagai pencari nafkah utama.

4. Adat tidak bertentangan dengan nilai syara' yang ada atau bertentangan dengan prinsip yang pasti.

Dalam hal ini bagi peneliti perlu diperhatikan terlebih dahulu motif istri dalam mengambil alih peran sebagai pencari nafkah utama, bila istri menjadi pencari nafkah utama karena ketidakmampuan suami sehingga istri rela menjadi pencari nafkah utama maka hal ini merupakan adat shohih yang tidak bertentangan dengan syara', Namun, jika istri sebagai pencari nafkah utama dikarenakan kelalaian suami akan tanggung jawabnya sehingga suami tidak bisa memenuhi kebutuhan rumah tangga, maka adat istri sebagai pencari nafkah utama 
termasuk kategori adat fasid karena adat tersebut bertentangan dengan peraturan agama, negara, dan sopan santun. 
Gambar 1. Bagan Istri Sebagai Pencari Nafkah Utama Perspektif Urf dan Akulturasi Budaya Redfield

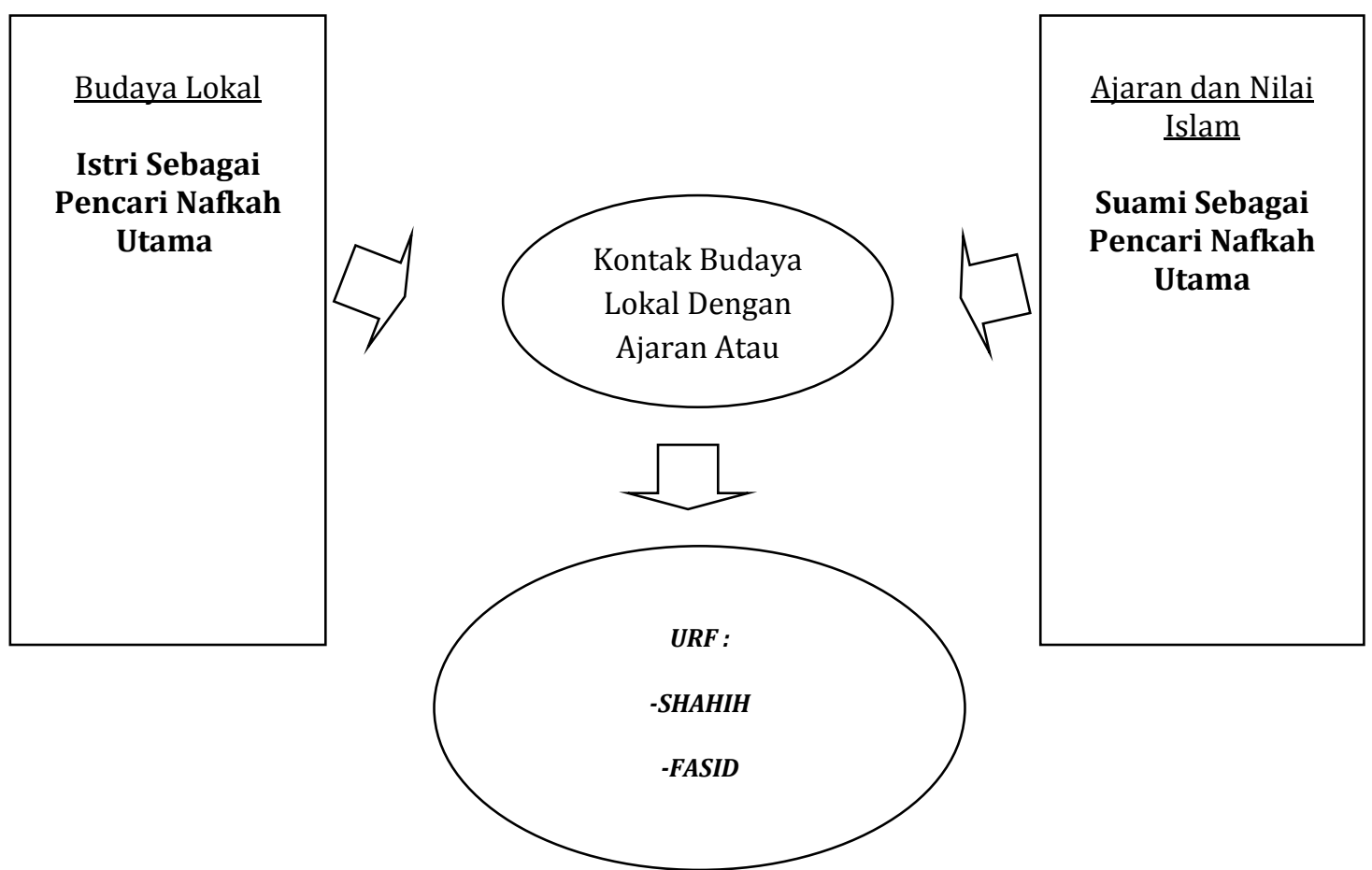

Faktor yang melatarbelakangi istri sebagai pencari nafkah utama. Adaptasi : Penyesuaian diri terhadap lingkungan hidup.

Kontak Langsung : Pertemuan antara dua budaya atau individu secara langsung.

Interaksi Sosial : Pengaruh timbal balik antara individu dengan individu lainnya.
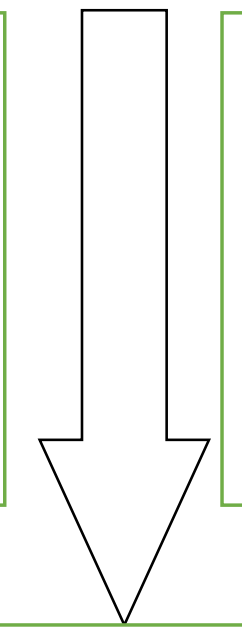

\section{Bentuk akulturasi budaya istri sebagai pencari nafkah utama.}

Sinkretisme : Percampuran antara tradisi lama dengan tradisi baru.

Orijinasi : Bertambahnya unsur baru untuk memenuhi unsur baru karena perubahan situasi.

Penolakan : Reaksi masyarakat yang tidak setuju akibat terjadinya akulturasi.

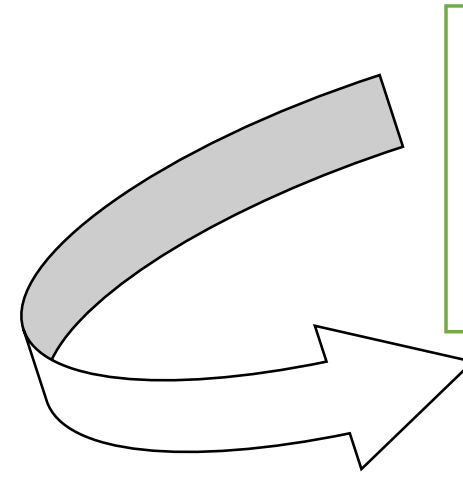

Budaya Baru

Kolaborasi Budaya

Lokal dengan Ajaran

dan Nilai Islam

Istri Sebagai Pencari Nafkah Utama di RW Sani Sari, Dusun Mundukkunci, Desa Tegalinggah, Provinsi Bali. 
Dari uraian di atas hal-hal yang melatarbelakangi istri sebagai pencari nafkah utama dapat disimpulkan sebagai berikut:

1. Adaptasi: contoh adaptasi pada penelitian ini dapat dilihat dari seringnya terjadi kontak langsung antara perempuan muslim dengan perempuanperempuan Hindu yang biasanya terjadi ketika mereka bekerja mencari nafkah sehingga perempuan muslim menjadi terbiasa kemudian beradaptasi terhadap apa yang dilakukan perempuan Hindu.

2. Kontak langsung: contoh kontak langsung dalam penelitian ini dapat dilihat melalui perdagangan antar muslim Bugis dengan masyarakat Bali, juga melalui jalur pernikahan antara kedua masyarakat tersebut, melalui kerjasama dalam bekerja dan melalui jalur pemerintahan, contoh melalui pemerintahan seperti terciptanya kesepakatan sekitar tahun 1970 antara masyarakat Hindu dengan masyarakat Islam jika dalam suatu pemerintahan diketuai oleh orang Hindu maka wakilnya harus dari orang Islam, begitupula sebaliknya. Pernyataan ini berdasarkan dengan hasil wawancara dengan Jamhuri di Tegalinggah 27 Oktober, 2018.

3. Interaksi sosial: interaksi sosial dalam hal ini dapat dilihat dari bertemunya sesama perempuan sebagai istri pencari nafkah utama sehingga terjalin keakraban di antara mereka.

Dalam mengamati akulturasi budaya, terdapat beberapa hal yang perlu diperhatikan di antaranya (Koentjadiningrat, 2009: 205) :

1. Keadaan masyarakat sebelum terjadi akulturasi.

2. Individu yang membawa unsur budaya asing.

3. Saluran yang dilalui budaya asing untuk masuk pada budaya lokal.

4. Bagian dari masyarakat yang terpengaruh budaya asing.

5. Reaksi individu yang terpengaruh unsur budaya asing.

Uraian yang menjelaskan setiap poin di atas adalah sebagai berikut:

1. Keadaan masyarakat Bali sebelum terjadi akulturasi.

Masyarakat Bali di Desa Tegalinggah sebelum datangnya agama Islam yang dibawa suku Bugis merupakan masyarakat yang beragama Hindu dengan kasta Waisya dan Sudra. Kasta merupakan pengelompokan masyarakat berdasarkan perannya dalam kehidupan sehari-hari. Kasta menurut umat Hindu di Bali dibagi menjadi empat yaitu kasta Brahmana,Ksatria, Waisya dan Sudra. Kasta Brahmana dijalankan oleh orang yang bertugas sebagai pendeta, kasta Ksatria dijalankan oleh pemimpin masyarakat, kasta Waisya dijalankan oleh pejabat pemerintahan sedangkan Sudra dijalankan oleh buruh dan tenaga lepas (Yanti, 2014). Kebanyakan penduduk Desa Tegalinggah di masa lalu berkasta Waisya dan Sudra, oleh karena itu banyaknya dijumpai perempuan bekerja kasar sebagai pencari nafkah utama tidak lain karena menjalankan budaya turun temurun sebagai kasta Sudra yang berlaku sejak berabad-abad yang lalu, pekerjaan yang dilakukan perempuan di desa ini tidak jauh beda dengan tugas kastanya yaitu bekerja kasar seperti buruh, bekerja serabutan, mengaspal jalan, memanjat pohon cengkeh, berjualan kapuk dan 
sebagainya. Sedangkan laki-laki pada masyarakat Hindu derajatnya dianggap lebih lebih tinggi daripada perempuan.

2. Individu yang membawa unsur budaya asing

Individu yang membawa unsur budaya asing dalam penelitian ini yaitu suku Bugis muslim yang merantau ke Bali. Orang muslim di Desa Tegalinggah merupakan keturunan suku Bugis yang berasal dari Sulawesi, dalam kesehariannya suku Bugis berpedoman dengan nilai Islam, karena seringnya terjadi kontak langsung antara suku Bugis dengan masyarakat Bali, maka terjadilah akulturasi budaya antara kedua suku tersebut yang mana dampak dari akulturasi tersebut lebih dirasakan pada pasangan suami istri yang beragama Islam.

3. Saluran yang dilalui budaya asing untuk masuk pada budaya lokal.

Perhatian terhadap individu asing yang masuk pada budaya lokal sehingga mempengaruhi budaya lokal penting untuk diketahui supaya diperoleh gambaran konkret terkait proses akulturasi yang terjadi pada masyarakat tersebut. Saluran yang dilalui budaya asing untuk masuk ke budaya lokal dalam penelitian ini melalui jalur perdagangan antara muslim Bugis dengan masyarakat Bali, juga melalui jalur pernikahan antara dua anggota budaya tersebut, melalui kerjasama dalam bekerja antara wanita Hindu dengan wanita Islam untuk memenuhi kebutuhan keluarga masing-masing, bekerja dalam hal ini seperti mengaspal jalan, memanjat cengkeh, menjual kapuk dan lain lain sehingga di antara wanita Hindu dan Islam tercipta sikap tenggang rasa dan interaksi sosial antara keduanya sehingga terjalin keakraban di antara mereka.

Di antara saluran yang dilalui budaya asing untuk masuk budaya lokal yaitu melalui jalur pemerintahan, contoh melalui jalur pemerintahan seperti terciptanya kesepakan sekitar tahun 1970 antara masyarakat Hindu dengan masyarakat Islam jika dalam suatu pemerintahan diketuai oleh orang Hindu maka wakilnya harus dari orang Islam, begitupula sebaliknya. Pernyataan ini berdasarkan dengan hasil wawancara dengan Jamhuri di Tegalinggah 27 Oktober, 2018.

4. Bagian masyarakat yang terpengaruh budaya asing.

Bagian masyarakat yang terpengaruh budaya asing juga penting untuk dipelajari. Adakalanya yang terkena hanya lapisan atas, rakyat jelata, tokoh atau kaum cendekiawan. Dalam penelitian ini bagian masyarakat yang terkena pengaruh budaya asing adalah wanita dari kalangan masyarakat muslim terutama pada suami yang tidak mampu memberi nafkah secara cukup atau suami yang tidak mampu bekerja sehingga wanita mengambil alih fungsi sebagai pencari nafkah utama.

5. Reaksi individu yang terpengaruh budaya asing.

Reaksi dari masyarakat yang menerima dan menolak adanya akulturasi merupakan objek kajian antropologi yang sangat luas. Dalam masyarakat pasti ada individu yang gampang menerima kebudayaan baru (progresif) juga ada individu yang menolak budaya tersebut (kolot). Pada penelitian ini terkait fenomena istri sebagai pencari nafkah utama tidak ada masyarakat Islam yang menerima istilah perempuan sebagai pencari nafkah utama karena pemahaman masyarakat Islam di Desa Tegalinggah mencari nafkah adalah tugas laki-laki, akan tetapi dalam 
prakteknya mereka cenderung menerima budaya istri sebagai pencari nafkah utama, karena dalam kehidupan sehari-hari banyak ditemukan pasangan suami istri muslim yang istrinya sebagai pencari nafkah utama.

Analisis hasil penelitian dikaitkan dengan teori akulturasi budaya. menurut Redfield ada enam hal yang terjadi dalam akulturasi, di antaranya: adisi, substitusi, penolakan, dekulturasi, sinkretisme, orijinasi. Dalam penelitian ini hanya ada tiga bentuk tampaknya akulturasi budaya pada fenomena istri sebagai pencari nafkah utama, ketiga bentuk itu di antaranya:

1. Orijinasi ialah bertambahnya unsur baru untuk memenuhi kebutuhan baru karena perubahan situasi. Dalam penelitian ini orijinasi dapat dilihat pada adanya hak waris yang diperoleh wanita Hindu ketika masuk agama Islam sebagai implikasi dari hak bersama suami istri, padahal sebelumnya wanita Hindu dimasa tuanya mereka tidak berhak mendapat warisan

2. Sinkretisme ialah perpaduan unsur-unsur budaya lama dengan kompleksnya unsur-unsur budaya baru dengan tidak meninggalkan jati diri masing-masing dan membentuk sistem kebudayaan baru dalam hal ini sinkretisme dapat dilihat dari adanya kerjasama antara suami istri untuk memenuhi kebutuhan keluarga yang sebelumnya laki-laki pada budaya Bali Hindu sebagian tidak bekerja menjadi bekerja, begitupula perempuan pada budaya Islam yang sebelumnya tidak mempunyai kewajiban bekerja.

3. Penolakan yaitu proses yang diakibatkan karena begitu cepatnya akulturasi terjadi sehingga sebagian masyarakat tidak siap menerimanya. Bentuk penolakan dalam hal ini terjadi dalam hal istilah pencari nafkah utama, suami tidak mau menganggap dirinya sebagai pihak yang dinafkahi sehingga istilah istri sebagai pencari nafkah utama diganti menjadi istri sebagai pembantu suami dalam memenuhi kebutuhan rumah tangga atau istri bekerja sama dengan suami dalam hal penafkahan.

Tabel 1. Proses Yang Terjadi Dalam Akulturasi

\begin{tabular}{|c|l|l|l|l|}
\hline No & \multicolumn{1}{|c|}{ Tradisi } & \multicolumn{1}{c|}{$\begin{array}{c}\text { Unsur } \\
\text { Akulturasi }\end{array}$} & \multicolumn{1}{c|}{ Keterangan } & \multicolumn{1}{c|}{ Hasil } \\
\hline 1 & $\begin{array}{l}\text { Istri sebagai } \\
\text { pencari nafkah } \\
\text { utama. }\end{array}$ & Penolakan & $\begin{array}{l}\text { Dimana } \\
\text { akulturasi terjadi } \\
\text { begitu cepat } \\
\text { sehingga } \\
\text { sebagian orang } \\
\text { tidak siap } \\
\text { menerimanya. }\end{array}$ & $\begin{array}{l}\text { Bentuk penolakan dalam hal } \\
\text { ini terjadi dalam hal istilah, } \\
\text { yaitu suami tidak mau } \\
\text { menganggap dirinya sebagai } \\
\text { pihak yang dinafkahi } \\
\text { melainkan istilah istri sebagai } \\
\text { pencari nafkah utama diganti } \\
\text { menjadi istri sebagai } \\
\text { pembantu suami dalam } \\
\text { memenuhi kebutuhan rumah } \\
\text { tangga atau istri bekerja sama } \\
\text { dengan suami dalam hal } \\
\text { penafkahan. }\end{array}$ \\
\hline
\end{tabular}




\begin{tabular}{|l|l|l|l|}
\hline & Sinkretisme & $\begin{array}{l}\text { Perpaduan unsur } \\
\text { lama dengan } \\
\text { yang baru } \\
\text { kemudian } \\
\text { membentuk } \\
\text { sebuah sistem } \\
\text { baru. }\end{array}$ & $\begin{array}{l}\text { Adanya kerjasama antara } \\
\text { suami istri untuk memenuhi } \\
\text { kebutuhan keluarga. }\end{array}$ \\
\hline & Orijinasi & $\begin{array}{l}\text { Adanya unsur } \\
\text { baru untuk } \\
\text { memenuhi } \\
\text { kebutuhan baru } \\
\text { karena terjadinya } \\
\text { perubahan } \\
\text { situasi. }\end{array}$ & $\begin{array}{l}\text { Orijinasi dapat dilihat pada } \\
\text { hak waris yang diperoleh } \\
\text { wanita Hindu ketika masuk } \\
\text { agama Islam sebagai implikasi } \\
\text { dari hak bersama suami istri. }\end{array}$ \\
\hline
\end{tabular}

\section{KESIMPULAN}

Adapun kesimpulan dalam jurnal ini adalah:

1. Terdapat tiga hal yang melatarbelakangi munculnya fenomena istri sebagai pencari nafkah utama di Dusun Mundukkunci, RW Sani Sari, Desa Tegalinggah, Kabupaten Singaraja, Provinsi Bali. Pertama. kurangnya penghasilan suami untuk memenuhi kebutuhan rumah tangga. Kedua, ketidakmampuan suami dalam mencari nafkah. Ketiga, faktor adat atau budaya turun-temurun.

2. Berdasarkan perspektif urf dari segi keabsahannya dalam pandangan syara' fenomena istri sebagai pencari nafkah utama dibagi dua Pertama, bila fenomena istri sebagai pencari nafkah utama disebabkan karena ketidakmampuan suami dalam mencari nafkah maka urf dalam konteks ini adalah urf shohih karena tidak bertentangan dengan syara'. Kedua, bila fenomena istri sebagai pencari nafkah utama dikarenakan kelalaian suami akan tanggung jawabnya, atau karena malasnya suami dalam bekerja untuk memenuhi kebutuhan rumah tangga maka adat istri sebagai pencari nafkah utama termasuk adat fasid karena adat tersebut bertentangan dengan peraturan agama, negara, dan sopan santun. Bentuk akulturasi budaya pada fenomena istri sebagai pencari nafkah utama di RW Sani Sari, Dusun Mundukkunci, Desa Tegalinggah, Kabupaten Singaraja, Bali ditinjau teori akulturasi budaya Redfield ada tiga. Pertama: orijinasi, bentuk orijinasi dalam hal ini dapat dilihat dari bertambahnya unsur baru yang memenuhi kebutuhan baru karena perubahan situasi. Dalam penelitian ini orijinasi dapat dilihat pada hak waris yang diperoleh wanita Hindu ketika masuk agama Islam sebagai implikasi dari hak bersama suami istri. Kedua, sinkretisme dalam penelitian ini dapat dilihat dengan adanya kerjasama antara suami istri dan tanggung jawab bersama untuk memenuhi kebutuhan keluarga. Ketiga, penolakan, bentuk penolakan dalam hal ini terjadi dalam hal istilah, yaitu suami tidak mau menganggap dirinya sebagai pihak yang dinafkahi sehingga istilah istri sebagai pencari nafkah utama diganti menjadi istri 
sebagai pembantu suami dalam memenuhi kebutuhan rumah tangga atau istri bekerja sama dengan suami dalam hal penafkahan.

\section{SARAN}

Kepada masyarakat terutama keluarga yang istri sebagai pencari nafkah utama, hendaknya mempertahankan rasa saling memahami, mempercayai, menghargai, membantu satu sama lain agar terwujud keluarga yang sakinah, mawaddah, warahmah.

Bagi tokoh masyarakat hendaknya memberikan arahan kepada keluarga yang istri sebagai pencari nafkah utama agar tradisi yang baik (urf shohih) yang dapat mendukung keluarga sakinah dan tidak terdapat kekerasan dalam rumah tangga dapat terwujud.

\section{DAFTAR PUSTAKA}

Adhiputra, Anak Agung Ngurah. (2013). Konseling Lintas Budaya. Cetakan Pertama, Yogyakarta, Graha Ilmu.

Arikunto, Suharsimi. (2006). Prosedur Penelitian Suatu Pendekatan Praktik. Jakarta, Rineka Cipta.

Asikin, Amirudin dan Zainal. (2006). Pengantar Metode Peneltian Hukum. Jakarta: Raja Grafindo Persada.

Bungin, Burhan. (2010). Ananlisis Data Penelitian Kualitatif. Jakarta: PT Raja Grafindo Persada.

Crewswell, John W.,. (2013). Penelitian Kualitatif \& Desain Riset Memilih Di Antara Lima Pendekatan. Yogyakarta: Pustaka Pelajar.

Dahlan, Abd Rahman. (2010). Ushul Fiqh. Jakarta: Amzah.

Firdaus. (2004) Ushul Fiqh Metode Mengkaji Dan Memahami Hukum Islam Secara Komprehensif. Jakarta:, Penerbit Zikrul Hakim.

Haroen, Nasrun. (1997). Ushul Fiqh, Logos Wacana Ilmu.

Islamiah, Nur Shofa Ulfiati. (2010). Isu - Isu Gender Kontemporer. Malang: UIN - MALIKI PRESS.

Koentjadiningrat, (2009). Pengantar Ilmu Antropologi. Cetakan kesepuluh. Jakarta: Penerbit Rineka Cipta.

Kompilasi Hukum Islam (KHI). Pasal 34 ayat (1) UU Perkawinan. Pasal 107 ayat (2) KUHPer. 
Pujileksono, Sugeng. (2015). Pengantar Antropologi Memahami Realitas Sosial Budaya, Malang: Intrans Publishing.

Sahrani, Tihami Sohari. (2014). Fiqh Munakahat Kajian Fiqh Nikah Lengkap. Jakarta: Rajawali Pers.

Sugiyono. (2017). Metode Penelitian Kualitatif. Bandung: Alfabeta.

Syafe'I, Rachmat. (1999). Ilmu Ushul Fiqh. Bandung: CV Pustaka Setia.

Syarifuddin, Amir. (2009). Ushul Fiqh. Jakarta: Kencana.

Thalib, Muhammad. (1999). Solusi Islam Terhadap Dilema Wanita Karir. Yogyakarta: Wihdah Press.

Undang - Undang Ri No 1 Tahun 1974 Tentang Perkawinan.

Utsman, Muhammad Ra'fat. (2017). Fiqih Khitbah dan Nikah, Depok: Fathan Media Prima.

Yanti, (2014). Ketut Leni, Ali Imron Dan Suparman Arif, Perkawinan Beda Kasta Pada Masyarakat Balinuraga Di Lampung Selatan, Artikel. 